\title{
Phase Changes of Enzyme Activity in Hind Gut Tissues of Piglets
}

\author{
M.G. Terenteva, R.N. Ivanova, G.A. Larionov \\ Department of biotechnology and processing of agricultural \\ products \\ Chuvash State Agricultural Academy \\ Cheboksary, Russia \\ maiya-7777@mail.ru
}

\author{
I.A. Alekseev, V.G. Semenov \\ Department of Morphology, Obstetrics and Therapy \\ Chuvash State Agricultural Academy \\ Cheboksary, Russia \\ semenov_v.g@list.ru
}

\begin{abstract}
This article describes nature and intensity of agerelated changes in the activity of transferases, phosphatases and a-amylase in the tissues of middle and bung guts of the large intestine of piglets in colostrum, colostrum-dairy, first, second and third dairy, dairy-plant, first and second plant phases of nutrition in the early postnatal period of systemogenesis. Activity of enzymes is determined by the spectrophotometric method in the scientific laboratory of the Chuvash State Agricultural Academy. It was revealed that high metabolic processes in the tissues of middle and bung guts of piglets are found in the colostrum, colostrum-dairy, and the first and second phases of the definitive nutrition. The lowest activity of metabolic processes is detected in the phases of the first, second and third dairy nutrition, and the second transition phase is in between. In the tissues of external and internal middle guts, the ALT activity is stabilized from the first definitive phase. Activity of AST, GGT and a-amylase in the tissues of external and internal middle guts is not stabilized during the studied early postnatal systemogenesis. Activity of ALP and AP in tissues of these guts is stabilized from the first definitive phase. ALT, AST, GGT and aamylase do not stabilize in the bung gut tissues during the studied early postnatal systemogenesis. ALP and AP activity in tissues of this gut is stabilized from the dairy-definitive phase.
\end{abstract}

Keywords-enzymes, nutrition phases, blind gut, middle gut, bung gut, piglets

\section{INTRODUCTION}

Studies on regularities investigation of enzyme systems formation in the tissues of visceral organs of animals $(1,2,6$, $7,9,11,15,16,18,22)$ indicate that the structural and functional development of organs after birth has several specific features.

Uneven intensity of metabolic processes in tissues of the digestive organs of growing piglets is consistent with hierarchy principle of the functional systems. Interaction of some functional systems in the whole organism is carried out by the neurophysiological mechanism of "current dominance": at any time, activity of the organism determines one or another functional system that satisfies the need, the main one - at the moment for survival - and maximum for adaptation to the external environment.
At the same time, predominance in one or another part of the digestive organ of some metabolic processes in different nutrition phases of mixed-age piglets indicates the principle of consistent interaction of functional systems. In the normal organism, functional systems consistently interact with each other, forming a continuous chain of functional activity, when the implementation of one system is successively replaced by the implementation of another system. A sequential chain of implementations of various functional systems with special centers of the nervous system is programmed and activated by a leading mechanism: each result of the activity of the implemented functional system based on the feedback of the nervous and humoral signaling is assessed by the respective control centers, after which the implementation of another functional system changes. Consistent implementation of the functional systems of the homeostatic series is strictly genetically predetermined and programmed.

In accordance with the structural and functional development of the digestive organs and in connection with changes in the nutritional structure of piglets, we distinguish the following phases of early postnatal systemogenesis: 1) colostrum; 2) colostrum-dairy (the first transition); 3) the first phase of dairy nutrition; 4) the second phase of the dairy nutrition; 5) the third phase of the dairy nutrition; 6) the dairydefinitive phase (the second transition); 7) the first phase of definitive nutrition; 8 ) the second phase of definitive nutrition (17).

\section{METHODS}

Age-related changes in the activity of aspartate aminotransferase (AST), alanine aminotransferase (ALT), $\gamma$-glutamyltransferase (GGT), a-amylase, alkaline (ALP) and acid phosphatases (AP) in the tissues of external and internal parts of middle, proximal and distal parts of the bung gut were determined of purebred piglets of large white breed grown in the pig farm of "Vurnarsky Meat-Processing Plant" OJSC, Vurnarsky district of the Chuvash Republic.

For studies piglets were used at the age of 1, 7, 14, 21, 28, 60,120 and 180 days, obtained from sows of 2-4 farrows, five heads at each age. In the study, boar pigs from a daily for two 
weeks of age and young hogs neutered at 11-13 days of age were used. Weaning of piglets was carried out at four weeks of age. In the pig complex a dry concentrate type of feeding is used with additional feedings in the form of prestarters and protein-vitamin- $\neg$ mineral supplements (PVMS).

Piglets euthanasia and all manipulations were performed in accordance with "Rules of work with use of experimental animals" (20). Guts of the large intestine were removed from the abdominal cavity, cleaned of the contents, washed with cold saline, divided into parts, and samples of their tissues were frozen in liquid nitrogen for further studies.

Activity of enzymes were determined in accordance with the methods in the scientific laboratory of the Chuvash State Agricultural Academy in the homogenates of the tissues of the guts by the spectrophotometric method (UV-1800) and using the reagent kit of the company "Vital Development Corporation" St. Petersburg.

OJSC. Calculation of enzyme activity was carried out according to the calibration schedule.

The degree of reliability of differences in average values was determined using the Student's test. For reliability of judgments, significance levels of $\mathrm{p}<0.05, \mathrm{p}<0.01$ and $\mathrm{p}$ $<0.001$ were divided.

\section{RESULTS AND DISCUSSION}

\section{A. Middle Gut}

After birth, during the first four days of life, the piglets are fed with colostrum during the colostrum nutrition phase. The structures and functions of the food functional systems of the colostrum phase are genetically programmed to ensure the assimilation of the components of colostrum to newborn piglets. According to our data (Table 1), in the tissues of the external and internal middle guts, activity of the studied enzymes is unequal in this nutrition phase of one-day piglets compared with other groups.

In the tissues of the external and internal middle guts in the colostrum phase of nutrition of piglets, in comparison with other phases of nutrition, the relatively high activity of ALT $19.8 \pm 0.94$ and $18.1 \pm 1.07$, AST-18.2 $\pm 1,06$ and $20.8 \pm 2.07$ and ALP is determined in the tissues of the external middle gut is $149.0 \pm 7.9$. Activity of GGT $-36.9 \pm 2.8$ and $149.1 \pm$ 9.7, a-amylase $-0.073 \pm 0.013$ and $0.254 \pm 0.021$ and AP -3.2 \pm 0.11 and $3.9 \pm 0.99$ is relatively low compared to other phase groups.

Thus, judging by the level of enzymes, in the colostrum phase of nutrition of piglets of the early postnatal period of systemic genesis of pigs, relatively high activity of protein metabolism with prevalence of transamination processes associated with the activity of alanine aminotransferase and alanine aminotransferase is found in the tissues of the external and internal middle gut. However, a relatively low rate of transfer of the g-glutamyl group from one peptide to another peptide or amino acid is found in the tissues of the external and internal middle gut compared with the subsequent phases of nutrition.
TABLE I. CHANGES IN THE ENZYMES ACTIVITY IN TISSUES OF THE MIDDLE GUT OF PIGLETS IN DIFFERENT PHASES OF POSTNATAL ONTOGENESIS

\begin{tabular}{|c|c|c|c|c|c|c|c|c|}
\hline $\begin{array}{l}\text { Age, } \\
\text { day }\end{array}$ & 1 & 7 & 14 & 21 & 28 & 60 & 120 & 180 \\
\hline \multicolumn{9}{|c|}{ ALT, mcM/g*hour } \\
\hline $\begin{array}{c}\text { Exter } \\
\text { nal }\end{array}$ & $\begin{array}{c}19.8 \pm \\
0.94\end{array}$ & $\begin{array}{c}11.8 \pm \\
0.79\end{array}$ & $\begin{array}{l}8.5 \pm \\
0.48\end{array}$ & $\begin{array}{l}9.4 \pm \\
0.43\end{array}$ & $\begin{array}{c}15.6 \pm \\
0.82\end{array}$ & $\begin{array}{c}16.8 \pm \\
0.64\end{array}$ & $\begin{array}{c}23.5 \pm \\
1.27\end{array}$ & $\begin{array}{c}21.6 \pm \\
1.19\end{array}$ \\
\hline $\begin{array}{c}\text { Inter } \\
\text { nal }\end{array}$ & $\begin{array}{c}18.1 \pm \\
1.07\end{array}$ & $\begin{array}{c}27.3 \pm \\
2.11\end{array}$ & $\begin{array}{c}10.4 \pm \\
0.61\end{array}$ & $\begin{array}{l}9.9 \pm \\
0.57\end{array}$ & $\begin{array}{c}16.0 \pm \\
0.79\end{array}$ & $\begin{array}{c}16.5 \pm \\
0.85\end{array}$ & $\begin{array}{c}39.3 \pm \\
2.88\end{array}$ & $\begin{array}{c}38.1 \pm \\
3.06\end{array}$ \\
\hline \multicolumn{9}{|c|}{ AST, mcM/g*hour } \\
\hline $\begin{array}{c}\text { Exter } \\
\text { nal }\end{array}$ & $\begin{array}{c}18.2 \pm \\
1.06\end{array}$ & $\begin{array}{c}10.5 \pm \\
0.43\end{array}$ & $\begin{array}{l}9.7 \pm \\
0.47\end{array}$ & $\begin{array}{c}10.9 \pm \\
0.34\end{array}$ & $\begin{array}{c}14.5 \pm \\
0.72\end{array}$ & $\begin{array}{c}18.9 \pm \\
0.88\end{array}$ & $\begin{array}{c}24.1 \pm \\
1.96\end{array}$ & $\begin{array}{c}36.5 \pm \\
2.16\end{array}$ \\
\hline $\begin{array}{c}\text { Inter } \\
\text { nal }\end{array}$ & $\begin{array}{c}20.8 \pm \\
2.07\end{array}$ & $\begin{array}{c}31.3 \pm \\
2.04\end{array}$ & $\begin{array}{l}9.9 \pm \\
0.28\end{array}$ & $\begin{array}{c}10.5 \pm \\
0.53\end{array}$ & $\begin{array}{c}18.2 \pm \\
0.96\end{array}$ & $\begin{array}{c}29.5 \pm \\
1.32\end{array}$ & $\begin{array}{c}38.5 \pm \\
2.34\end{array}$ & $\begin{array}{c}49.6 \pm \\
3.09\end{array}$ \\
\hline \multicolumn{9}{|c|}{ a-amylases, $\mathrm{mg} /\left(\mathrm{s}^{*} \mathrm{~g}\right)$} \\
\hline $\begin{array}{c}\text { Exter } \\
\text { nal }\end{array}$ & $\begin{array}{c}0.073 \pm \\
0.013 \\
\end{array}$ & $\begin{array}{c}0.182 \pm \\
0.012\end{array}$ & $\begin{array}{c}0.239 \pm \\
0.011\end{array}$ & $\begin{array}{c}0.233 \pm \\
0.014\end{array}$ & $\begin{array}{c}0.257 \pm \\
0.017 \\
\end{array}$ & \begin{tabular}{|c|}
$0.199 \pm$ \\
0.012 \\
\end{tabular} & $\begin{array}{c}0.251 \pm \\
0.017 \\
\end{array}$ & \begin{tabular}{|c}
$0.354 \pm$ \\
0.028 \\
\end{tabular} \\
\hline Inter & $0.254 \pm$ & $0.231 \pm$ & $0.338 \pm$ & $0.179 \pm$ & $0.192 \pm$ & $0.137 \pm 0$ & $0.234 \pm$ & $0.491 \pm$ \\
\hline \multicolumn{9}{|c|}{ ALP, mcM/g*hour } \\
\hline $\begin{array}{c}\text { Exter } \\
\text { nal }\end{array}$ & $\begin{array}{c}149.0 \pm \\
7.9\end{array}$ & \begin{tabular}{|c|}
$157.9 \pm$ \\
9.4
\end{tabular} & \begin{tabular}{|c|}
$175.4 \pm$ \\
6.2
\end{tabular} & $\begin{array}{c}91.1 \pm \\
6.8\end{array}$ & $\begin{array}{c}45.5 \pm \\
3.8\end{array}$ & $\begin{array}{c}88.3 \pm \\
5.6\end{array}$ & $\begin{array}{c}79.8 \pm \\
3.8\end{array}$ & $\begin{array}{c}78.0 \pm \\
5.3\end{array}$ \\
\hline $\begin{array}{c}\text { Inter } \\
\text { nal }\end{array}$ & $\begin{array}{c}53.4 \pm \\
5.3\end{array}$ & \begin{tabular}{|c|}
$60.3 \pm$ \\
3.3
\end{tabular} & $\begin{array}{c}97.7 \pm \\
5.1\end{array}$ & $\begin{array}{c}46.2 \pm \\
3.1\end{array}$ & \begin{tabular}{|l|}
$52.1 \pm$ \\
4.3
\end{tabular} & $\begin{array}{c}77.6 \pm \\
4.9\end{array}$ & $\begin{array}{c}87.5 \pm \\
5.8\end{array}$ & $\begin{array}{c}76.4 \pm \\
3.9\end{array}$ \\
\hline \multicolumn{9}{|c|}{ AP, mcM/g*hour } \\
\hline $\begin{array}{c}\text { Exter } \\
\text { nal }\end{array}$ & $\begin{array}{l}3.2 \pm \\
0.11\end{array}$ & $\begin{array}{l}3.6 \pm \\
0.19\end{array}$ & $\begin{array}{c}13.3 \pm \\
1.06\end{array}$ & $\begin{array}{c}14.9 \pm \\
1.13\end{array}$ & $\begin{array}{c}12.6 \pm \\
0.97\end{array}$ & $\begin{array}{l}3.1 \pm \\
0.14\end{array}$ & $\begin{array}{l}2.8 \pm \\
0.17\end{array}$ & $\begin{array}{l}2.8 \pm \\
0.11\end{array}$ \\
\hline $\begin{array}{c}\text { Inter } \\
\text { nal }\end{array}$ & $\begin{array}{l}3.9 \pm \\
0.09 \\
\end{array}$ & $\begin{array}{l}3.7 \pm \\
0.17 \\
\end{array}$ & $\begin{array}{l}9.7 \pm \\
0.72 \\
\end{array}$ & $\begin{array}{l}9.0 \pm \\
0.59 \\
\end{array}$ & $\begin{array}{l}9.2 \pm \\
0.83 \\
\end{array}$ & $\begin{array}{l}3.3 \pm \\
0.17 \\
\end{array}$ & $\begin{array}{l}2.9 \pm \\
0.12 \\
\end{array}$ & $\begin{array}{l}3.1 \pm \\
0.12 \\
\end{array}$ \\
\hline \multicolumn{9}{|c|}{ GGT, mcM/g*hour } \\
\hline $\begin{array}{c}\text { Exter } \\
\text { nal }\end{array}$ & $\begin{array}{c}36.9 \pm \\
2.8\end{array}$ & $\begin{array}{c}109.3 \\
\pm 5.3\end{array}$ & $\begin{array}{c}260.7 \\
\pm 7.6\end{array}$ & $\begin{array}{c}180.6 \\
\pm 6.6\end{array}$ & $\begin{array}{c}167.5 \\
\pm 9.6 \\
\end{array}$ & $\begin{array}{c}179.4 \\
\pm 5.8\end{array}$ & $\begin{array}{c}164.8 \\
\pm 6.3\end{array}$ & $\begin{array}{c}397.2 \\
\pm 7.9\end{array}$ \\
\hline $\begin{array}{c}\text { Inter } \\
\text { nal }\end{array}$ & $\begin{array}{c}149.1 \\
\pm 6.7\end{array}$ & $\begin{array}{c}156.1 \\
\pm 9.7\end{array}$ & $\begin{array}{l}192.8 \\
\pm 10.6 \\
\end{array}$ & $\begin{array}{c}61.9 \\
4.2 \\
\end{array}$ & $\begin{array}{l}267.8 \\
\pm 11.4\end{array}$ & $\begin{array}{c}274.8 \\
\pm 9.7\end{array}$ & $\begin{array}{c}266.6 \\
\pm 7.8\end{array}$ & $\begin{array}{c}467.8 \\
\pm 6.7\end{array}$ \\
\hline
\end{tabular}

In the colostrum phase of nutrition of piglets in terms of subsequent nutrition phases, a relatively high intensity of the processes of hydrolysis of phosphoric acid esters involving alkaline phosphatase is also detected. However, activity of amylolytic processes that provide necessary energy to the cells of tissues and rate of exchange of organophosphorus compounds, carried out using acid phosphatase in the tissues of the colon, is low.

During the first 5-7 days of life of the piglets, in the first transitional, colostrum-dairy phase of the nutrition of the early postnatal period of system genesis, the composition of the incoming food in the digestive organs changes significantly: amount of organic components decreases, proportion of water increases. A newly-advanced functional nutrition system changes the structure and function of the tissues of the external and internal middle gut of growing piglets, adapts the guts to the absorption of new food components, which affects the activity of the studied enzymes in the tissues of the studied guts.

In the tissues of the external gut of seven-day-old piglets, in the colostrum-dairy phase, activity of ALT and AST is significantly reduced, respectively by $40.4 \%, \mathrm{p}<0.001$, to 11.8 \pm 0.79 and by $42.3 \%, p<0.001$ to $10.5 \pm 0.43$. On the contrary, in the internal middle gut tissues these enzymes significantly increase, respectively, 1.5 times, $p<0.01$, to 27.3 \pm 2.01 and 1.5 times, $p<0.01$, to $31.3 \pm 2.04$. Activity of GGT in the colostrum-dairy phase of nutrition increases 
significantly in the tissues of the external middle gut 2.9 times, $\mathrm{p}<0.001$, to $109.3 \pm 5.3$, and in the tissues of the internal middle gut enzyme activity remains at the level of the colostrum phase. Activity of a-amylase also increases in the tissues of the external middle gut 2.5 times, $\mathrm{p}<0.001$, to 0.182 \pm 0.012 , while in the tissues of the internal middle gut enzyme activity remains at the level of the colostrum phase. Activity of ALP and AP in this phase of nutrition does not change.

Thus, in the colostrum-dairy phase of nutrition in the tissues of external and internal middle guts, a relatively high activity of protein metabolism in the tissues of the internal middle gut is determined with the predominance of transamination processes, associated with aspartate aminotransferase activity and a high transfer rate of the gglutamyl group from one peptide to another peptide or per amino acid. In the tissues of the external middle gut in the colostrum-dairy phase, intensity of protein metabolism is low due to decrease in activity of alanine aminotransferase and preservation of activity of gamma-gluamyl transferase at the level of the colostrum phase. An increase in the intensity of amylolytic processes in the tissues of the external middle gut and absence of phase-related phase changes in the tissues of the internal middle gut are detected in the colostrum-dairy phase of the piglet nutrition. In this phase of piglets nutrition, intensity of the processes of hydrolysis of phosphoric acid esters involving alkaline and acid phosphatases remains at the level of the colostrum phase.

In the first phase of the dairy nutrition, from 8 to 14 days of life, the piglets are switched to maternal milk nutrition. At the same time, in the farm, at 8 days of age, piglets are additionally fed prestarter in accordance with the instructions for use. Under the conditions of the changed composition of incoming food in two-week-old piglets in the tissues of the external and internal middle guts, ALT activity decreases, respectively, by $28.0 \%, \mathrm{p}<0.05$, to $8.5 \pm 0.48$ and by $61.9 \%$, $p$ $<0.001$, to $10.4 \pm 0.61$. AST activity in the tissues of the external middle gut is maintained at the level of colostrumdairy phase, and in the internal middle gut tissues it is significantly reduced by $68.4 \%, p<0.001$, to $9.9 \pm 0.28$. GGT activity in the first phase of dairy nutrition increases significantly in the tissues of the external middle gut 2.4 times, $\mathrm{p}<0.001$, to $260.7 \pm 7.6$, and in the tissues of the internal middle gut it also increases significantly 1.2 times, $\mathrm{p}<0,05$, to $192.8 \pm 12.6$. A-amylase activity increases 1.3 times in the tissues of the external middle gut, $p<0.05$, to $0.239 \pm 0.011$, in the tissues of the internal middle gut enzyme activity increases 1.5 times, $\mathrm{p}<0.01$, to $0.338 \pm 0.26$. ALP activity in the tissues of the external middle gut increases unreliable 1.1 times, $\mathrm{p}>$ 0.05 , to $175.4 \pm 6.2$, in the tissues of the internal middle gut it increases significantly, 1.6 times, $p<0.001$, to $97,7 \pm 5.1$. AP activity increases dramatically in the tissues of the external middle gut 3.7 times, $\mathrm{p}<0.001$, to $13.3 \pm 1.06$ and in the tissues of the internal middle gut -2.6 times, $\mathrm{p}<0.001$, to 9.7 \pm 072 .

Thus, in the first dairy phase of nutrition, in the tissues of the external and internal middle guts, the relatively low activity of protein metabolism is determined due to decrease in the intensity of transamination processes associated with activity of alanine aminotransferase and aspartate aminotransferase. At the same time, proteolytic processes associated with the transfer of the g-glutamyl group from one peptide to another peptide or to an amino acid increase. In the first dairy phase of the piglets nutrition, increase in the intensity of amylolytic processes is revealed in the tissues of the external middle gut and in the tissues of the internal middle gut. In this phase of piglets nutrition a relatively high intensity of hydrolysis processes of phosphoric acid esters with the participation of alkaline and acid phosphatases is discovered.

In the second phase of dairy nutrition of piglets, from 15 to 21 days old, amount of incoming milk to the middle gut increases significantly. In terms of changes in the quantity and composition of incoming food for three-week-old piglets, the character of phase age-related changes of ALT and AST in the tissues of the external and internal middle gut, compared with the previous one, with the first dairy phase of the piglets nutrition, does not change significantly. GGT activity during the next week of life of the piglets in the tissues of the external and internal middle guts is significantly reduced, respectively, by $30.7 \%, \mathrm{p}<0.001$, to $180.6 \pm 6.6$ and by $67.9 \%, \mathrm{p}<0.001$, to $61,9 \pm 4.21$. Activity of a-amylase in the tissues of the external middle gut will remain at the level of the previous first dairy phase, in the tissues of the internal middle gut it drops significantly, by $47.1 \%, p<0.001$, to $0.179 \pm 0.009$. AP activity during the second phase of milk nutrition of piglets in the tissues of the external and internal middle gut is significantly reduced by $48.1 \%, \mathrm{p}<0.001$, to $91.1 \pm 6.8$ and by $52.7 \%, \mathrm{p}<0.001$, to 46 , respectively, $2 \pm 3.1$. Activity of AP during the second dairy phase is maintained at a relatively high level.

Thus, in the second dairy phase of nutrition, in the tissues of the external and internal middle guts, a relatively low activity of protein metabolism is determined due to a decrease in the intensity of transamination processes associated with the activity of alanine aminotransferase and aspartate aminotransferase and a decrease in the rate of transfer of the $g$ glutamyl group from one peptide to another peptide or amino acid. In the second lactic phase of nutrition of piglets, intensity of amylolytic processes in the tissues of the external middle gut does not change, while in the tissues of the internal middle gut it decreases significantly. In this phase of piglet nutrition, a relatively low intensity of the processes of hydrolysis of phosphoric acid esters with the participation of alkaline phosphatase and the preservation of the high rate of these processes with the participation of acid phosphatase is detected.

In the third phase of dairy feeding of piglets, from 22 to 28 the daily age, when amount of incoming milk to the middle gut continues to increase significantly, the incoming milk with components of prestarter is significantly enriched. In the tissues of the external and internal middle gut, activity of ALT increases 1.7 times, respectively, $p<0.001$, to $15.6 \pm 0.82$ and 1.6 times, $\mathrm{p}<0.001$, to $16.0 \pm 0.64$. Activity of AST also significantly increases, respectively, 1.3 times, $p<0.01$, to $14.5 \pm 0.72$ and 1.7 times, $p<0.001$, to $18.2 \pm 0.96$. The level of GGT in the tissues of the external middle gut in this phase of nutrition does not change, and in the tissues of the internal middle gut increases sharply 4.3 times, $p<0.001$, to $267.8 \pm$ 
11.4. Activity of a-amylase in the third phase of the dairy nutrition in comparison with the previous phase in the tissues of the external and internal middle gut changes insignificantly. Activity of alkaline phosphates in the tissues of the external middle gut decreases significantly, by $50.1 \%$, p $<0.001$, to $45.5 \pm 3.8$. However, in the tissues of the internal middle gut, it remains at the level of the previous phase. Activity of AP is maintained at a high level both in the tissues of the external and in the tissues of the internal middle gut.

Thus, in the third dairy phase of nutrition in the tissues of the external and internal middle guts, a relatively high activity of protein metabolism is determined due to an increase in the rate of transamination processes associated with the activity of alanine aminotransferase and aspartate aminotransferase and with an increase in the transfer rate of the g-glutamyl group from one peptide to another peptide or an amino acid in the tissues of the internal middle gut and maintaining these processes in the tissues of the external middle gut at the same level. In the third dairy phase of nutrition of piglets, intensity of amylolytic processes with the participation of a-amylase in the tissues of the external and internal middle guts does not change. In this phase of piglet nutrition, a decrease in the intensity of hydrolysis processes of phosphoric acid esters involving alkaline phosphatase in the tissues of the external middle gut and a small unreliable increase in the tissues of the internal middle gut are detected. The rate of hydrolysis of phosphoric acid esters involving acid phosphatase in the tissues of the external and internal middle guts remains at a high level of the previous phase.

In the second transitional, dairy-definitive phase of piglets nutrition, from 29 to 60 days old, when piglets are transferred to the basic diet with the addition of dairy products and PVMS, quantity and quality of the incoming components with food in the digestive organs significantly change. Forming nutrition functional systems change the structure and functions of the digestive organs, which is expressed by a change in the activity of enzyme systems in their tissues, including the studied enzymes. In the tissues of the external and internal middle guts, activity of ALT of two-month-old piglets remains unchanged and is determined at the level of four weeks. Activity of AST in this phase of nutrition of piglets in the tissues of both middle guts significantly increases, respectively, 1.3 times, $\mathrm{p}<0.05$, to $18.9 \pm 0.88$ and 1.6 times, $\mathrm{p}<0.001$, to $29.5 \pm 1.32$. Activity of GGT in the tissues of both middle guts by the age of two months does not change significantly. Activity of a-amylase in the dairy-definitive phase of nutrition compared with the previous phase in the tissues of the external and internal middle guts reliably decreases, respectively, by $22.6 \%, \mathrm{p}<0.05$, to $0.199 \pm 0.012$ and by $28.7 \%, p<0,05$, to $29.5 \pm 1.32$. Activity of alkaline phosphatase in the second transitional phase of nutrition of piglets increases significantly: in the tissues of the external middle gut -1.9 times, $p<0.001$, up to $88.3 \pm 5.5$, and in the tissues of the internal middle gut -1.5 times, $\mathrm{p}<0.01$, up to $77.6 \pm 4,9$. AP activity in this phase of piglets nutrition in the tissues of both middle guts drops sharply by $75.4 \%$, p $<0.001$, to $3.1 \pm 0.14$ by $64.2 \%, p<0.001$, to $3.3 \pm 0.17$.

Thus, in the dairy-definitive nutritional phase of piglets in the tissues of the external and internal middle guts, protein metabolism activity remains at the level of the previous phase due to the unchanged rate of transamination processes associated with alanine aminotransferase activity and stability of transfer of the g-glutamyl group from one peptide to another peptide or per amino acid. In the transitional phase of piglets nutrition, intensity of the processes of hydrolysis of starch and glycogen with the participation of $\alpha$-amylase in the tissues of the external and internal middle guts is significantly reduced. In this phase of piglets nutrition in tissues of the external and internal middle guts, a significant increase in the intensity of the hydrolysis processes of phosphoric acid esters involving alkaline phosphatase is determined. The rate of hydrolysis of phosphoric acid esters involving acid phosphatase in the tissues of the external and internal middle gut decreases sharply.

In the first definitive nutritional phase of piglets, from 60 to 120 daily age, when piglets are put on the basic diet with the addition of PVMS, quantity and quality of incoming ingredients from food to the digestive organs changes significantly. The forming functional food systems adapt the structure and functions of the digestive organs to the peculiarities of the incoming feed, which is expressed by a change in the activity of enzyme systems in their tissues, including the studied enzymes.

In the tissues of the external and internal middle guts, activity of ALT of four-month-old piglets significantly increases, respectively, 1.4 times, $\mathrm{p}<0.01$, to $23.5 \pm 1.27$ and 2.4 times, $\mathrm{p}<0.001$, to $39.3 \pm 2.88$. Activity of AST in this phase of nutrition also significantly increases, respectively, 1.3 times, $\mathrm{p}<0.05$, to $24.1 \pm 1.96$ and 1.3 times, $\mathrm{p}<0.05$, to $38.5 \pm$ 2,34 . Activity of GGT in the tissues of both middle guts by four months of age does not change significantly. Activity of a-amylase in the first definitive phase of nutrition in comparison with the previous phase in the tissues of the external and internal middle guts significantly increases, respectively, 1.3 times, $p<0.05$, to $0.251 \pm 0.017$ and 1.7 times, $\mathrm{p}<0.001$ up to $0.234 \pm 0.011$. Activity of alkaline phosphatase and AP in the tissues of the external and internal middle guts is stabilized from two months of age.

Thus, in the first definitive nutritional phase of piglets in the tissues of the external and internal middle guts, protein metabolism activity increases due to an increase in the intensity of reanimation processes involving alanine aminotransferase and aspartate aminotransferase and the stability of transfer of the g-glutamyl group from one peptide to another peptide or amino acid. In the first definitive phase of piglets nutrition, intensity of the processes of hydrolysis of starch and glycogen with the participation of a-amylase in the tissues of the external and internal middle guts also increases significantly.

During the subsequent, second, definitive phase of nutrition of piglets, from 120 to 180 days of life of the early postnatal period of systemic genesis of pigs, in the tissues of the external and internal middle guts the activity of ALT does not change significantly, remains at the level of four months. Activity of AST in this phase of nutrition increases significantly, respectively, 1.5 times, $\mathrm{p}<0.01$, to $36.5 \pm 2.16$ and 1.3 times, $p<0.05$, to $49.6 \pm 3,09$. By the age of six 
months, activity of GGT in the tissues of both middle guts noticeably increases 2.4 times, $\mathrm{p}<0.001$, to $397.2 \pm 7.9$ and 1.8 times, $\mathrm{p}<0.001$, to $467.8 \pm 6,7$. Activity of a-amylase in the second definitive phase of nutrition, compared with the previous phase, in tissues of the external and internal middle guts significantly increases, respectively, 1.4 times, $\mathrm{p}<0.05$, to $0.354 \pm 0.028$ and 2.1 times, $\mathrm{p}<0.001$ to $0.491 \pm 0.021$.

Thus, in the second definitive phase of nutrition of the piglets to the tissues of the external and internal middle guts, protein metabolism activity increases due to an increase in the intensity of transamination processes involving aspartate aminotransferase and accelerating the transfer of the gglutamyl group from one peptide to another peptide or amino acid. In the second definitive phase of the piglet nutrition, intensity of the hydrolysis of starch and glycogen with the participation of a-amylase in the tissues of the external and internal middle guts increases significantly.

Apparently, during the period of early postnatal systemogenesis of pigs studied by us, the structural-chemical and morpho-functional formation of the tissues of the external and internal middle guts does not end.

\section{B. Bung Gut}

After birth, during the first four days of life, the piglets feed on colostrum while in the colostrum phase of nutrition. Structures and functions of the food functional systems of the colostrum phase are genetically programmed to ensure the absorption of colostrum components to newborn piglets. According to our data (Table 2), in this phase of nutrition of one-day-old piglets, compared with other groups, in the tissues of different organs of the digestive system, activity of the studied enzymes is not the same.

In the tissues of the proximal and distal parts of the bung gut, when compared with data from other age-related nutritional phases, relatively high ALT activity is determined, respectively $35.4 \pm 2.18$ and $33.8 \pm 1.07$. At the same time, activity of GGT, respectively, is $27.1 \pm 0.7$ and $73.8 \pm 4.2$, the activity of a-amylase is $0.123 \pm 0.009$ and $0.248 \pm 0.021$, the activity of APs is $22.1 \pm 1.62$ and $42.7 \pm 3.19$ and KF $-2.9 \pm$ 0.12 and $3.2 \pm 0.14$ compared with other phase groups has the lowest value. Activity of AST is intermediate among other phase groups and is $20.5 \pm 1.09$ and $23.2 \pm 0.87$. Thus, judging by the level of enzymes, in the tissues of the proximal and distal parts of the bung gut compared with the subsequent phases of nutrition, relatively high activity of protein metabolism is found in the colostrum phase of nutrition of piglets in the early postnatal period of systemic pigmentation, due to the high intensity of transamination processes associated with increased alanine aminotransferase activity and moderate aspartate aminotransphrase activity. However, the rate of transfer of the g-glutamyl group from one peptide to another peptide or to amino acid, is slowed. Activity of amylolytic processes that provide the necessary energy to cells and tissues in the tissues of the proximal and distal parts of this gut is at a relatively low level. In the tissues of both studied parts of the bung gut in the colostrum of piglets relative to the subsequent feeding phases, a slowed-down rate of the processes of hydrolysis of phosphoric acid esters with the participation of acidic and alkaline phosphatases is also detected.

TABLE II. CHANGES IN THE ENZYMES ACTIVITY IN THE TISSUES OF BUNG GUT OF PIGLETS IN DIFFERENT PHASES OF POSTNATAL ONTOGENESIS

\begin{tabular}{|c|c|c|c|c|c|c|c|c|}
\hline $\begin{array}{l}\text { Age } \\
\text { dav }\end{array}$ & 1 & 7 & 14 & 21 & 28 & 60 & 120 & 180 \\
\hline \multicolumn{9}{|c|}{ ALT mcM/g*hour } \\
\hline Proxi & $35.4 \pm$ & $20.7 \pm$ & $10.4 \pm$ & $14.3 \pm$ & $13.2 \pm$ & $15.1 \pm$ & $17.2 \pm$ & $34.9 \pm$ \\
\hline ma & 2.18 & 0.67 & 0.38 & 0.71 & 0.49 & 0.64 & 0.86 & 2.34 \\
\hline Dist & $33.8 \pm$ & $21.3 \pm$ & $9.6 \pm$ & $15.8 \pm$ & $16.4 \pm$ & $17.9 \pm$ & $18.6 \pm$ & $36.1 \pm$ \\
\hline al & 1.07 & 1.18 & 0.23 & 0.99 & 0.32 & 1.07 & 0.83 & 2.12 \\
\hline \multicolumn{9}{|c|}{ AST mcM/g*hour } \\
\hline Proxi & $20.5 \pm$ & $36.7 \pm$ & $7.2 \pm$ & $6.9 \pm$ & $13.9 \pm$ & $32.2 \pm$ & $29.3 \pm$ & $40.8 \pm$ \\
\hline ma & 1.09 & 2.33 & 0.28 & 0.17 & 0.66 & 2.36 & 1.86 & 2.44 \\
\hline \begin{tabular}{|l|} 
Dist \\
al \\
\end{tabular} & $\begin{array}{l}23.1 \pm \\
0.87\end{array}$ & \begin{tabular}{|l|}
$38.1 \pm$ \\
3.06
\end{tabular} & $\begin{array}{l}7.8 \pm \\
0.19\end{array}$ & $\begin{array}{l}8.9 \pm \\
0.48\end{array}$ & $\begin{array}{l}13.5 \pm \\
0.59\end{array}$ & $\begin{array}{l}29.1 \pm \\
1.37\end{array}$ & $\begin{array}{l}28.3 \pm \\
1.19\end{array}$ & $\begin{array}{l}45.1 \pm \\
3.05\end{array}$ \\
\hline \multicolumn{9}{|c|}{ 2- g -glutamyltransferase $\mathrm{mcM} / \mathrm{g} *$ hour } \\
\hline Proxi & $27.1 \pm$ & $91.0 \pm$ & $131.8 \pm$ & $52.2 \pm$ & $221.3 \pm$ & $293.6 \pm$ & 170.4 & 287.6 \\
\hline ma & 0.7 & 4.6 & 4.9 & 2.4 & 6.3 & 6.9 & 7.7 & 9.7 \\
\hline \begin{tabular}{|l|} 
Dist \\
al \\
\end{tabular} & $\begin{array}{l}73.8 \pm \\
4.2\end{array}$ & $\begin{array}{l}142.8 \pm \\
7.3\end{array}$ & $\begin{array}{l}261.3 \pm \\
6.7 \\
\end{array}$ & $\begin{array}{l}73.9 \pm \\
3.3 \\
\end{array}$ & \begin{tabular}{|l|}
$321.4 \pm$ \\
7.5
\end{tabular} & \begin{tabular}{|l|}
$418.4 \pm$ \\
8.3
\end{tabular} & $\begin{array}{l}135.1 \pm \\
5.4\end{array}$ & $\begin{array}{l}310.1 \pm \\
8.4\end{array}$ \\
\hline \multicolumn{9}{|c|}{ ALP mcM/g * *ho } \\
\hline Proxi & $22.1 \pm$ & $22.5 \pm$ & $50.7 \pm$ & $26.2 \pm$ & $\beta 0.1 \pm$ & $43.3 \pm$ & $49.9 \pm$ & $50.7 \pm$ \\
\hline 1 & 1.61 & 1.16 & 3.99 & 0.93 & 2.19 & 2.84 & 3.11 & 4.15 \\
\hline $\begin{array}{l}\begin{array}{l}\text { Dist } \\
\text { al }\end{array} \\
\end{array}$ & $\begin{array}{l}42.7 \pm \\
3.19 \\
\end{array}$ & $\begin{array}{l}43.3 \pm \\
3.02\end{array}$ & $\begin{array}{l}56.9 \pm \\
2.08 \\
\end{array}$ & $\begin{array}{l}27.3 \pm \\
1.02 \\
\end{array}$ & $\begin{array}{l}32.2 \pm \\
2.26\end{array}$ & $\begin{array}{l}49.3 \pm \\
3.03 \\
\end{array}$ & $\begin{array}{l}45.8 \pm \\
4.09 \\
\end{array}$ & $\begin{array}{l}2.3 \pm \\
4.88 \\
\end{array}$ \\
\hline \multicolumn{9}{|c|}{ AP mcM/g } \\
\hline Proxi & $2.9 \pm$ & $3.3 \pm$ & $7.4 \pm$ & $3.2 \pm$ & $11.1 \pm$ & $2.3 \pm$ & $2.6 \pm$ & $2.5 \pm$ \\
\hline ma & 0.12 & p.13 & 0.23 & 0.46 & 0.75 & 0.11 & 0.009 & p.007 \\
\hline Dist & $3.2 \pm$ & $2.9 \pm$ & $7.9 \pm$ & $3.3 \pm$ & $11.7 \pm$ & $2.9 \pm$ & $2.6 \pm$ & $2.8 \pm$ \\
\hline al & 0.14 & p.08 & 0.28 & 0.39 & p.81 & 0.006 & 0.006 & p.011 \\
\hline \multicolumn{9}{|c|}{ a-Amylase mg/(s*h) } \\
\hline Proxi & $0.123 \pm$ & $0.132 \pm$ & $0.247 \pm$ & $0.099 \pm$ & $0.113 \pm$ & $0.199 \pm$ & $0.280 \pm$ & $0.489 \pm$ \\
\hline ma & 0.009 & 0.013 & 0.011 & 0.008 & p.008 & 0.018 & 0.011 & p.022 \\
\hline \begin{tabular}{|l}
$\begin{array}{l}\text { Dist } \\
\text { al }\end{array}$ \\
\end{tabular} & \begin{tabular}{|l}
$.248 \pm$ \\
0.021 \\
\end{tabular} & $\begin{array}{l}0.224 \pm \\
0.011\end{array}$ & $\begin{array}{l}0.286 \pm \\
0.017\end{array}$ & $\begin{array}{l}0.202 \pm \\
0.015\end{array}$ & $\begin{array}{l}0.195 \pm \\
0.014\end{array}$ & $\begin{array}{l}0.291 \pm \\
0.013\end{array}$ & $\begin{array}{l}0.278 \pm \\
0.016\end{array}$ & $\begin{array}{l}0.530 \pm \\
.031 \\
\end{array}$ \\
\hline
\end{tabular}

During the first 5-7 days of life of piglets, in the first transitional, colostrum-dairy phase of the early postnatal period of systemogenesis, compound of the incoming chyme in the bung gut significantly changes: the amount of organic components decreases, proportion of water increases. The newly-advanced functional nutrition system changes the structure and functions of the tissues of this gut of growing piglets, adapts the gut to the elimination of new components of the chyme, which affects the activity of the studied enzymes in the tissues of the studied parts of this gut. In the tissues of the proximal and distal parts of the bung gut of seven-day-old piglets, in colostrum-dairy phase of the nutrition phase, the activity of ALT decreases, respectively, by $41.6 \%, p<0.001$, to $20.7 \pm 0.67$ and by $37.0 \%, \mathrm{p}<0.001$ up to $21.3 \pm 1.18$. Activity of AST, on the contrary, increases, respectively, 1.8 times, $\mathrm{p}<0.001$, to $36.7 \pm 2.33$ and 1.6 times, $\mathrm{p}<0.01$ to 38.1 
\pm 3.06. Activity of GGT in this phase of nutrition also significantly increases, respectively, 3.3 times, $\mathrm{p}<0.001$, to $91.0 \pm 4.6$ and 1.9 times, $p<0.001$, to $142.8 \pm 7.3$. Activity of a-amylase, ALP and AP in the colostrum-dairy phase of nutrition is maintained at the level of the colostrum phase.

Thus, judging by the level of enzymes, in the tissues of the proximal and distal parts of the bung gut compared with the subsequent phases of nutrition, a relatively high activity of protein metabolism is found in the colostatic-milk phase of nutrition of piglets of the early postnatal period of pigs, associated with increased activity of aspartate aminotransferase and also with a high rate of transfer of the gglutamyl group from one peptide to another peptide or amino acid. Activity of amylolytic processes that provide necessary energy to cells and tissues in the tissues of the proximal and distal parts of this gut is at the level of the colostrum phase. In the tissues of both studied parts of the bung gut in the colostrum of piglets relative to the subsequent feeding phases, a slowed-down rate of the processes of hydrolysis of phosphoric acid esters with the participation of acidic and alkaline phosphatases is also detected.

In the first phase of the dairy nutrition, the piglets get their mother's milk. In the farm, piglets from the age of 8 days, are additionally fed with prestarter in accordance with the application instructions. Under the conditions of the modified structure of incoming food of two-week-old piglets in the tissues of the proximal and distal parts of the bug gut, ALT activity significantly decreases, respectively, by $49.8 \%$, p $<0.001$, to $10.4 \pm 0.38$ and by $55.0 \%, \mathrm{p}<0.001$, up to $9.6 \pm$ 0.23 . AST activity in the first dairy phase also significantly decreases, respectively, by $80.4 \%, \mathrm{p}<0.001$, to $7.2 \pm 0.28$ and by $70.5 \%, p<0.001$, to $7.8 \pm 0.19$. GGT activity in this phase of dairy nutrition of piglets significantly increases, respectively, 1.4 times, $\mathrm{p}<0.001$, to $131.8 \pm 4.9$ and 1.8 times, $\mathrm{p}<0.001$, to $261.3 \pm 6.7$. A-amylase activity also significantly increases: in the tissues of the proximal part - 1.9 times, $p$ $<0.001$, up to $0.247 \pm 0.011$; in the tissues of the distal part 1.3 times, $\mathrm{p}<0.05$, to $0.286 \pm 0.017$. In the first dairy phase of nutrition, ALP activity significantly increases: in the tissues of the proximal part 2.2 times, $\mathrm{p}<0.001$, up to $50.7 \pm 3.99$; in the tissues of the distal part -1.3 times, $\mathrm{p}<0.05$, up to $56.9 \pm 3.08$. Phase increase of AP activity is significant, respectively -2.2 times, $\mathrm{p}<0.001$, to $7.4 \pm 0.23$ and 2.7 times, $\mathrm{p}<0.001$, to $7.9 \pm$ 0.28 .

Thus, in the first phase of dairy nutrition of piglets, the level of transamination processes involving alanine aminotransferase and asparataminotrnferase decreases and at the same time the transfer rate of the g-glutamyl group from one peptide to another peptide or amino acid with the participation of gamma-glutamyl transferase increases. During this phase of nutrition, activity of amylolytic processes that provide the necessary energy to cells and tissues, in the tissues of the proximal and distal parts of the bung gut with the participation of a-amylase also increases. The rate of hydrolysis of phosphoric acid esters in the tissues of the proximal and distal parts of the bung gut with the participation of acidic and alkaline phosphatases is high.
In the second phase of dairy nutrition of piglets, from 15 to 21 days old, in conditions of increasing amount of incoming milk to the digestive organs and increasing number of components of prestarter, three-week-old piglets do not detect significant phase-related changes in the activity of ALT and AST in the tissues of the proximal and distal parts of the bung gut. GGT activity in the second phase of the dairy nutrition of piglets in the tissues of both parts of the bung gut decreases sharply, according by $60.4 \%, \mathrm{p}<0.001$, to $52.2 \pm 2.4$ and by $71.7 \%, \mathrm{p}<0.001$, to $73.9 \pm 3.3$. A-amylase activity also significantly decreases in the tissues of the proximal and distal parts of the bung gut, respectively, by $60.0 \%$, p $<0.001$, to $0.099 \pm 0.009$ and by $29.4 \%, p<0.0 .05$, up to $0.202 \pm 0.015$. In this phase of nutrition of piglets ALP activity is decrease, respectively, by $48.3 \%, \mathrm{p}<0.001$, to $26.2 \pm 0.93$ and by $52.1 \%, \mathrm{p}<0.001$, to $27.3 \pm 1.02$. AP activity of $\mathrm{CF}$ in the tissues of both parts of the rectum is maintained at the level of the first phase of the milk diet

Thus, in the second phase of the dairy nutrition of the piglets in the proximal and distal parts of the bung gut, no significant phase changes in the activity of proteolytic processes involving alanine aminotransferase and aspartate aminotransferase are detected. At the same time, the rate of transfer of the g-glutamyl group from one peptide to another peptide or to amino acid with the participation of gammaglutamyl transferase is significantly reduced. In this phase of dairy nutrition, intensity of hydrolysis of polysaccharides with the participation of a-amylase and exchange rate of phosphoric acid ester compounds with the participation of alkaline phosphatase also decreases. Exchange rate of phosphoric acid ester compounds involving acid phosphatase is maintained at the level of the first phase of the dairy diet.

In the third phase of dairy nutrition of piglets, from 22 to 28 daily age, when amount of incoming milk to the digestive organs continues to increase significantly, incoming milk is significantly enriched with components of prestarter, in the tissues of the external and distal parts of the bung gut ALT activity remains at the level of the second phase of nutrition. AST activity in this phase of nutrition increases significantly in both parts of the bung gut respectively, 2.0 times, $p<0.001$, to $13.9 \pm 0.66$ and 1.5 times, $p<0.001$, to $13.5 \pm 0,59$. During the third phase of the dairy nutrition in the tissues of the proximal and distal parts of the bung gut, GGT activity significantly increases 4.2 times, $\mathrm{p}<0.001$, to $221.3 \pm 6.3$ and 4.3 times, $\mathrm{p}<0.001$, to $321.4 \pm 7.5$. A significant phase change in the activity of a-amylase and ALP in the tissues of the proximal and distal parts of the bung gut in the third phase of the dairy nutrition of the piglets is not detected. AP activity in this phase of nutrition increases significantly in the tissues of both parts of the bung gut, respectively, 1.3 times, $p<0.05$, to $11.1 \pm 0.75$ and 1.4 times, $p<0.05$, to $11,7 \pm 0.81$.

Thus, in the third phase of dairy nutrition of piglets, a significant increase in the intensity of proteolytic processes involving aspartate aminotransferase and increase in the activity of protein metabolism processes with inclusion of gglutamyl aminotransferase occur in both parts of the bung gut. Rate increase of the exchange of phosphoric acid essential compounds in the third phase of the dairy nutrition of piglets in the bung gut tissues is carried out with the participation of 
acid phosphatase. The rate of transamination of amino acids with the participation of alanine aminotransferase, as well as the hydrolysis of starch and glycogen with the participation of a-amylase remains at the level of the second phase of nutrition.

In the second transitional, dairy-definitive phase of piglets nutrition, from 29 to 60 days old, when piglets are transferred to the basic diet with the addition of dairy products and PVMS, quantity and quality of the incoming components with food in the digestive organs significantly change. Forming nutrition functional systems change the structure and functions of the digestive organs, which is expressed by a change in the activity of enzyme systems, including studied enzymes. ALT activity of ALT in the tissues of the external and distal parts of the bung gut remains at the level of the third phase of the dairy nutrition. AST activity in the dairy-definitive phase of piglets nutrition in the tissues of both parts of the bung gut increases significantly, 2.3 times, respectively, $\mathrm{p}<0.001$, up to $32.2 \pm$ 2.36 and 2.2 times, $p<0.001$, up to $29,1 \pm 1.37$. GGT activity, under conditions of this phase, also significantly increases, respectively, 1.3 times, $\mathrm{p}<0.01$, to $293.6 \pm 6.9$ and 1.3 times, $\mathrm{p}<0.01$, to $418.4 \pm 83$. In the dairy-definitive phase of nutrition, a significant phase increase of $\alpha$-amylase activity is determined in the tissues of the proximal and distal parts of the bung gut 1.8 times, $\mathrm{p}<0.001$, up to $0.199 \pm 0,018$ and 1.5 times, $\mathrm{p}<0.01$, up to $0.291 \pm 0.013$. ALP activity to the twomonth-old piglets significantly increases in the tissues of both parts of the bung gut, respectively, 1.4 times, $p<0.01$, to 43.3 \pm 2.84 and 1.5 times, $\mathrm{p}<0.01$, to $493 \pm 3.03$. AP activity, on the contrary, drops dramatically, according by $79.3 \%$, p $<0.001$, to $2.3 \pm 0.11$ and by $75.2 \%, \mathrm{p}<0.001$, to $2.9 \pm 0.006$.

Thus, in the dairy-definitive phase of nutrition of piglets, as in the third phase of dairy nutrition, high intensity of proteolytic processes is associated with increased activity of aspartate aminotransferase and increased activity of protein metabolism processes with the inclusion of GGT. Rate of transamination of amino acids with the participation of alanine aminotransferase is low. Intensity of hydrolysis of starch and glycogen with the participation of a-amylase in the transitional phase of nutrition increases. Rate of exchange of phosphoric acid ester compounds in this phase of feeding piglets in the tissues of the rectum increases with the participation of alkaline phosphatase.

From the age of two months of piglets in the tissues of the proximal and distal parts of the bung gut, ALP activity is at the maximum level, and AP activity at the minimum level is stabilized.

In the first definitive nutritional phase of piglets, from 60 to 120 daily age, when piglets are transferred to the main diet with the addition of PVMS, the activity of metabolic processes in the rectal tissues associated with the participation of such enzymes as ALT and AST is maintained at the level of the dairy-definitive phase. GGT activity in the tissues of the proximal and distal parts, compared with the previous phase, decreases, respectively, by $42.0 \%, \mathrm{p}<0.001$, to $170.4 \pm 7.7$ and by $67.7 \%, \mathrm{p}<0.001$, to $135.1 \pm 5.4$. A-amylase activity significantly increases only in the tissues of the proximal part, 1.4 times, $\mathrm{p}<0.01$, to $0.280 \pm 0.011$.
Thus, in the first definitive nutritional phase of piglets, intensity of amino acid transamination processes involving alanine aminotransferase and aspartate aminotransferase does not change compared to the previous phase and the rate of protein metabolism with the inclusion of g-glutamyl aminotransferase decreases. Process intensity of hydrolysis of starch and glycogen with the participation of a-amylase in the first definitive phase of nutrition increases in the tissues of the proximal part of the gut, and rate of hydrolysis of polysaccharides does not change in the tissues of the distal part of the gut.

In the second definitive phase of piglet nutrition, from 120 to 180 days old, when piglets are in the fattening group, the proportion of meat and bone meal in the diet increases - in the tissues of the proximal and distal parts of the bung gut activity of such enzymes as ALT, AST, GGT and a- amylase significantly increases. ALT activity increases, respectively, 2.0 times, $\mathrm{p}<0.001$, to $34.9 \pm 2.34$ and 1.9 times, $\mathrm{p}<0.001$, to $36.1 \pm 2.12$. AST activity in this phase increases, respectively, 1.4 times, $\mathrm{p}<0.01$, to $40.8 \pm 2.44$ and 1.9 times, $\mathrm{p}<0.01$, to $45.1 \pm 3.05$. GGT activity increases, respectively, 1.7 times, $\mathrm{p}$ $<0.001$, to $287.6 \pm 9.7$ and 2.3 times, to $310.1 \pm 8.4$. Activity of a-amylase increases, respectively, 1.7 times, $\mathrm{p}<0.001$, to $0.489 \pm 0.022$ and 1.9 times to $0.530 \pm 0.031$.

From these research results it follows that in the second definitive nutritional phase of piglets in the tissues of the proximal and distal parts of the bung gut, intensity of amino acid transamination processes involving alanine aminotransferase and aspartate aminotransferase increases, compared to the previous phase, the rate of protein metabolism with g-glutamyl transferase increases, processes of hydrolysis of starch and glycogen with the participation of a-amylase in the tissues of both parts of the gut significantly increase. Apparently, age-related structural-chemical improvement and morpho-functional formation of the middle gut in the studied period of piglets life of the early postnatal system genesis of pigs does not end.

Thus, summarizing the results of studies to establish the nature of phase changes in the rate of metabolic processes in the tissues of the studied guts of piglets in the early postnatal systemogenesis, it can be concluded that high metabolic processes in the tissues of the middle and bung guts of piglets are detected in the colostrum, colostrum-dairy and the first and the second phases of the definitive nutrition. The lowest activity of metabolic processes is detected in the phases of the first, second and third dairy nutrition and the second transition phase is in between.

The results of our research confirm that principles of the organization of dynamic interaction of functional systems are based on the selective maturation of functional systems and their individual units in the process of postnatal systemogenesis. Throughout the individual life of living organisms, functional systems are formed by the very course of the vital processes that determine the sequential formation, genesis, interaction, and subsequent destruction of certain functional systems. Functional systems are not formed simultaneously. Some functional systems, especially of the metabolic and homeostatic levels, are genetically determined, 
others are added in process of formation and meet primarily metabolic needs. Dynamically formed functional systems adapt the structures and functions of the digestive organs of growing piglets to the final result, to the assimilation of the constantly changing composition and amount of feed $(8,13$, $14,19,23)$.

In the tissues of external and internal middle guts, the ALT activity is stabilized from the first definitive phase. AST, GGT and a-amylase activity in the tissues of the external and internal middle guts during the studied early postnatal systemogenesis is not stabilized. Activity of ALP and AP in the tissues of these guts is stabilized from the first definitive phase. ALT, AST, GGT and a-amylase do not stabilize in the bung gut tissues during the studied early postnatal systemogenesis. Activity of ALP and AP in the tissues of this gut is stabilized from the dairy-definitive phase.

Thus, judging by the stabilization of the activity of the studied enzymes during the studied early postnatal systemogenesis, the structural and chemical formation of tissues and the maturation of food functional systems in them, in the middle and bung guts of pigs does not end. Our data are consistent with the selectivity principle of maturation of individual units of functional systems in accordance with the ecological characteristics of animals $(3,4,5,10,12,21)$.

\section{References}

[1] A.A. Manokhin, L.V. Reznichenko, V.N. Karaichentsev, "Effect of vitamin-enzyme preparations on the physiological state of piglets", Memoirs of Bauman Kazan State Academy of Veterinary Medicine, 2017, Vol. 232, No. 4, pp. 108-112.

[2] A.N. Silyukova, N.G. Ignatiev, G.M. Efremova, "Phosphatases and aamylase in liver tissues of rabbits during transitional and vegetative phase of nutrition", Vestnik of Ulyanovsk State Agricultural Academy, 2016, Vol. 33, No. 1, P. 50-55.

[3] V. Kofler, "The concept of the "expanded viewpoint" and the theory of functional systems", XXII Congress of I.P. Pavlov Physiological Society, Volgograd: VolgGMU Press, 2013, pp. 9

[4] V.V. Sherstnev, "The concept of systemogenesis and modern vision of the idea of process unity of the development of integrative brain activity", pp.5-22 [VIII Amosovsky Readings, Moscow, 2007]

[5] V.I. Fyodorov, "Classification of control systems of the body, Supplement to the theory of the functional system of P. K. Anokhin", Advances in modern biology, 2000, vol. 120, No. 1, pp. 3-11.

[6] V.I. Fisinin, I.A. Egorov, V.G. Vertiprakhov, A.A. Grozina, T.N. Lenkova, V.A. Manukyan, T.A. Egorova, "Activity of digestive enzymes in the duodenal chyme and blood plasma in original strains and hybrids of meat chickens when using food supplements in the diet", Agricultural Biology, 2017, Vol. 52, No. 6, pp. 1226-1233.

[7] V.S. Grigoriev, G.V. Molyanova, "Effect of thymosin-a1 on the dynamics of transamination enzymes activity of pigs", Memoirs of Bauman Kazan State Academy of Veterinary Medicine, 2012, Vol. 211, pp. 255-258.

[8] V.F. Lysov, Functional systems of farm animals, Kazan, KGVI, 1986, p 76.

[9] G.V. Molyanova, "Effect of thymosin-a1 on the dynamics of enzymes of transamination in the blood of pigs during warm and cold period of the year", Bulletin of Samara State Agricultural Academy, 2015, No. 1, pp. 25-29.

[10] G.L. Drandrov, "Clinical analysis of functional systems", pp. 334-335 [XVIII Congress of I.P. Pavlov Physiological Society, Kazan, 2001]

[11] E.I. Troshin, Yu.G. Krysenko, "The dynamics of enzymatic activity in the associated form of porcine circovirus", Bulletin of Bashkir State Agrarian University, 2012, No. 2, pp. 33-35.

[12] E.L. Golubeva, "Origins of the systemogenesis concept and prospects for its further development", Moscow: Meditsina, 1980, p. 280

[13] K.V. Sudakov, "Development of the theory of functional systems in the scientific school of P.K. Anokhin", Herald of the International Academy of Science, 2011, No. 1, pp. 1-5.

[14] K.V. Sudakov, "The Theory of Functional Systems: a new approach to the problem of physiological processes integrating in the body", Russian Journal of Physiology, 2002, No. 12, Vol. 88, pp. 1590-1599.

[15] M.G. Terenteva, N.V. Mardarieva, T.V. Kuznetsova, "Amylase and phosphatase activity in gut tissues of growing purebred and hybric piglets", RUDN Journal, Series: Agronomy and Animal breeding, 2013, No. 3, pp. 53-59.

[16] N.G. Ignatiev, M.G. Terenteva, "Gamma-glutamyltransferase in duodenal tissues of baby rabbits", Vestnik of Ulyanovsk State Agricultural Academy, 2016, vol. 34, No. 2, pp. 101-105.

[17] N.G. Ignatiev, "Phases of the early postnatal period of ontogenesis of pigs", Memoirs of Bauman Kazan State Academy of Veterinary Medicine, 2015, Vol. 224, pp. 83-86.

[18] N.N. Ivanova, N.G. Ignatiev, "Aminotransferase activity in liver tissues of mixed-age piglets", Memoirs of Bauman Kazan State Academy of Veterinary Medicine, 2010, Vol. 204, pp. 98-103.

[19] P.K. Anokhin, Topical points of the functional system theory, Moscow: Nauka, 1980, p. 196

[20] Work Code involving experimental animals. Appendix to the order of the Ministry of Health of the USSR No. 775 of 12/03/1977 (http://docs.cntd.ru/document/456016716)

[21] T.E. Kostina, Physiological features of functional systems of pigs, Kazan: Kazan Veterinary Institute Press, 1982, p. 80

[22] T.S. Mironycheva, L.K. Kamenek, N.V. Terekhina, "Activity of some enzymes in rat liver homogenate as a result of magnesium hydroxoaluminate introduction", Journal of Pharmacy and Chemistry, 2013, Vol. 47, No. 1, pp. 43-44.

[23] The theory of systemogenesis, K.V. Sudakova, Eds. Moscow: Gorizont, 1997, p. 567 